Бояринова К. О.

канд. економ. наук, доцент, ORCID ID: 0000-0001-5879-2213

Копішинська К.О.

канд. економ. наук, ORCID ID: 0000-0002-1609-2902

Національний технічний університет Украӥни «Киїський політехнічний інститут імені Ігоря Сікорського»

\title{
ОСОБЛИВОСТІ ЗАКОНОДАВЧОГО РЕГУЛЮВАННЯ ДІЯЛЬНОСТІ СТАРТАП-КОМПАНІЙ В УКРАЇНІ
}

\section{ОСОБЕННОСТИ ЗАКОНОДАТЕЛЬНОГО РЕГУЛИРОВАНИЯ ДЕЯТЕЛЬНОСТИ СТАРТАП-КОМПАНИЙ В УКРАИНЕ}

\section{PECULIARITIES OF LEGISLATIVE REGULATION OF STARTUP COMPANIES ACTIVITY IN UKRAINE}

У статті розглянуто правові засади регулювання діяльності стартап-компаній в Украӥні. Відсутність визначення терміну «стартап» на законодавчому рівні зумовиланеобхідність фактичного регулювання такого виду діяльності у рамках законів та законодавчих актів, які стосуються окремих напрямів та особливостей діяльності стартап-компаній. Визначено законодавчі акти, щуо регулюють діяльність стартапів в Україні. Необхідність діяти у правовому полі зумовила потребу у виборі засновниками організаційно-правової форми стартапу. На початковому етапі функціонування пропонується використовувати одну з таких форм: фізична особа-підприємець, приватне підприсмство або товариство з обмеженою відповідальністю. Визначено переваги та недоліки використання зазначених форм. Важливим аспектом діяльності стартапів $\epsilon$ охорона прав інтелектуальної власності авторів та розробників нових ідей. Зокрема, автори мають можливість оформлювати патенти на винаходи, авторські свідоитва, ноу-хау тощз залежно від характеру об 'єкту інтелектуальної власності.

Ключові слова: стартап, законодавче регулювання, інтелектуальна власність, регулювання діяльності стартап-компаній.

В статье рассмотрены правовые основы регулирования деятельности стартапкомпаний в Украине. Отсутствие определения термина «стартап» на законодательном уровне обусловливало необходимость регулирования такого вида деятельности в рамках законов и законодательных актов, касающихся отдельных направлений и особенностей деятельности стартап-компаний. Определены законодательные акты, регулируюшие деятельность стартапов в Украине. Необходимость действовать в правовом поле обусловилапотребность в выборе учредителями организационно-правовой формы стартапа. На начальном этапе функиионирования предлагается использовать одну из следуюших форм: физическое лицо-предприниматель, частное предприятие или общество c ограниченной ответственностью. Определены преимущества и недостатки использования указанных форм. Важным аспектом деятельности стартапов является охрана прав интеллектуальной собственности авторов и разработчиков новых идей. $B$ 
частности, авторы имеют возможность оформлять патенты на изобретения, авторские свидетельства, ноу-хау и т.д. в зависимости от характера объекта интеллектуальной собственности.

Ключевые слова: стартап, законодательное регулирование, интеллектуальная собственность, регулирование деятельности стартап-компаний.

The article considers the legal bases of regulating the activities of startup companies in Ukraine. The lack of definition of "startup" at the legislative level causes necessity of regulation of such activity within the framework of laws and regulations relating to certain areas and features of the activities of startup companies.There were determined the legal acts regulating the startups activities in Ukraine. The necessity to act within the legal field causes the need for the founders to choose the legal form of a startup. At the initial stage of operating it is proposed to use one of the following forms: individual entrepreneur, private company or a limited liability company. The advantages and disadvantages of using these forms were identified. An important aspect of startup activity is to protect the intellectual property rights of authors and developers of new ideas. In particular, the authors have the opportunity to register patents for inventions, inventors' certificates, know-how, while the choice depends on the nature of intellectual property object.

Keywords: startup, legislative regulation, intellectual property, regulation of startup companiesactivity.

Вступ. Ринок стартапів в Україні постійно зростає, так за підсумками 2015 року він продемонстрував зростання на рівні 20-30\%. Найбільш динамічною сферою для стартапів $\epsilon$ інформаційні технології (IT).У 2015 році від продажу IT-продуктів і послуг Україна отримала понад 2,5 млрд. дол. США експортної виручки - на 25\% більше, ніж роком раніше. Зростають не тільки доходи IT-сектора, але і кількість працюючих в ньому. За підсумками 2015-го в країні налічувалося близько 90 000- 100000 осіб, зайнятих в IT. Це один 3 найвищих показників в Свропі, але, навіть незважаючи на це, фахівців в Україні не вистачає. Аутсорсингові компанії - найбільший роботодавець для місцевих технічних фахівців. В Україні дев'ять 3 десяти зайнятих в цій сфері працюють саме в сегменті аутсорсингу. Він і генерує більшу частину виручки IT-сектора. Велика кількість успішних ІT-підприємців отримали в аутсорсингових компаніях досвід i знання, за допомогою яких змогли запустити власний бізнес [1]. Отже, зростання кількості стартап-компаній актуалізує потребу у визначенні особливостей законодавчого регулювання їх діяльності в Україні.

Частково питання правового регулювання діяльності стартапів висвітлювали в своїх публікаціях Д.Збанацький [11], Ю. Підодвірна [13], Н.Полякова [14], проте недостатньо висвітленими залишись питання законодавчого забезпечення діяльності стартап-компаній в Україні, а також особливості охорони прав інтелектуальної власності авторів та розробників ідей. 
Постановка завдання.Метою дослідження $є$ визначення особливостей законодавчого регулювання діяльності стартап-компаній в Україні та охорони прав інтелектуальної власності авторів та розробників ідей залежно від їх специфіки.

Методологія. У роботі використовуються методи наукового узагальнення (для визначення основних законів та законодавчих актів, стосуються окремих напрямів та особливостей діяльності стартап-компаній), аналізу та синтезу (під час виявлення найбільшприйнятнихна початковому етапі організаційно-правових форм стартапів та встановлення особливостей охорони прав інтелектуальної власності авторів ідей та винаходів).

Результати дослідження.Перш за все, варто зазначити, що у вітчизняному законодавстві на даний момент термін «стартап» відсутній. Тому регулювання такого виду діяльності здійснюється у рамках законів та законодавчих актів, які стосуються окремих напрямів та особливостей діяльності стартапів.

Нормативно-правову основу ведення діяльності стартапів та інвестиційної діяльності в Україні становлять законодавчі акти, наведені в табл. 1.

Табличя 1

Законодавчі акти, що регулюють діяльність стартапів в Україні

\begin{tabular}{|c|c|c|}
\hline № & Законодавчий акт & Характеристика \\
\hline 1 & $\begin{array}{l}\text { Закони України «Про } \\
\text { підприємництво» від } \\
7 \text { лютого } 1991 \text { р.№ } \\
\text { 698-XII }\end{array}$ & $\begin{array}{l}\text { Визначає загальні правові, економічні та соціальні засади } \\
\text { підприємницької діяльності (підприємництва) громадян та } \\
\text { юридичних осіб на території України, встановлює гарантії } \\
\text { свободи підприємництва та його державної підтримки. }\end{array}$ \\
\hline 2 & $\begin{array}{l}\text { Закон України «Про } \\
\text { інвестиційну } \\
\text { діяльність» } \\
\text { 18.09.1991 р. №1560- } \\
\text { XII }\end{array}$ & $\begin{array}{l}\text { Визначає загальні правові, економічні та соціальні умови } \\
\text { інвестиційної діяльності на території України.. }\end{array}$ \\
\hline 3 & $\begin{array}{l}\text { Закон України «Про } \\
\text { режим іноземного } \\
\text { інвестування» від } \\
\text { 19.03.1996 р. №93/96- } \\
\text { ВР }\end{array}$ & $\begin{array}{l}\text { Визначає особливості режиму іноземного інвестування на } \\
\text { території України, виходячи з цілей, принципів і положень } \\
\text { законодавства України. }\end{array}$ \\
\hline 4 & $\begin{array}{l}\text { Закон України «Про } \\
\text { інноваційну } \\
\text { діяльність» від } \\
\text { 04.07.2002 p.№40-IV }\end{array}$ & $\begin{array}{l}\text { Визначає правові, економічні та організаційні засади } \\
\text { державного регулювання інноваційної діяльності в Україні, } \\
\text { встановлює форми стимулювання державою інноваційних } \\
\text { процесів і спрямований на підтримку розвитку економіки } \\
\text { України інноваційним шляхом. }\end{array}$ \\
\hline 5 & $\begin{array}{l}\text { Закон України «Про } \\
\text { наукові парки» від } \\
\text { 25.06.2009 р. №1563- } \\
\text { VI }\end{array}$ & $\begin{array}{l}\text { Закон регулює правові, економічні, організаційні відносини, } \\
\text { пов'язані зі створенням і функціонуванням наукових парків, } \\
\text { та спрямований на інтенсифікацію процесів розроблення, } \\
\text { впровадження, виробництва інноваційних продуктів та } \\
\text { інноваційної продукції на внутрішньому і зовнішньому }\end{array}$ \\
\hline
\end{tabular}




\begin{tabular}{|c|c|c|}
\hline & & ринках. \\
\hline 6 & $\begin{array}{l}\text { Закон України «Про } \\
\text { авторське право та } \\
\text { суміжні права» від } \\
23.12 .1993 \text { р. №3792- } \\
\text { XII }\end{array}$ & $\begin{array}{l}\text { Закон охороняє особисті (немайнові) і майнові права авторів } \\
\text { та іх правонаступників, пов'язані із створенням та } \\
\text { використанням творів науки, літератури і мистецтва } \\
\text { (авторське право), і права виконавців, виробників фонограм } \\
\text { та організацій мовлення (суміжні права). }\end{array}$ \\
\hline 7 & $\begin{array}{l}\text { Закон України «Про } \\
\text { охорону прав на } \\
\text { винаходи i корисні } \\
\text { моделі» від } 15.12 .1993 \\
\text { p. №3687-XII }\end{array}$ & $\begin{array}{l}\text { Закон регулює відносини, що виникають у зв'язку з } \\
\text { набуттям і здійсненням права інтелектуальної власності на } \\
\text { винаходи і корисні моделі в Україні. }\end{array}$ \\
\hline 8 & $\begin{array}{l}\text { Закон України «Про } \\
\text { охорону прав на знаки } \\
\text { для товарів і послуг» } \\
\text { від 15.12.1993 p. } \\
\text { №3689-XII }\end{array}$ & $\begin{array}{l}\text { Закон регулює відносини, що виникають у зв'язку } 3 \\
\text { набуттям і здійсненням права власності на знаки для товарів } \\
\text { і послуг в Україні. }\end{array}$ \\
\hline 9 & $\begin{array}{l}\text { Закон України «Про } \\
\text { захист персональних } \\
\text { даних» від 01.06.2010 } \\
\text { р. №2297-VI }\end{array}$ & $\begin{array}{l}\text { Закон регулює правові відносини, пов’язані із захистом і } \\
\text { обробкою персональних даних, і спрямований на захист } \\
\text { основоположних прав і свобод людини і громадянина, } \\
\text { зокрема права на невтручання в особисте життя, у зв'язку } 3 \\
\text { обробкою персональних даних. }\end{array}$ \\
\hline
\end{tabular}

Джерело: складено авторами з використанням [2-11]

Діяльність засновників стартапу дуже схожа 3 підприємницькою діяльністю (в деяких випадкахїх можна назвати підприємцями).

Відповідно до Закону України «Про підприємництво», підприємництво - це безпосередня самостійна, систематична і на власний ризик діяльність по виробництву продукції, виконанню робіт, наданню послуг з метою отримання прибутку. Вона здійснюється фізичними та юридичними особами, зареєстрованими як суб'єкти підприємницької діяльності у порядку, встановленому законодавством [2].

Таким чином, підприємництво - це, по-перше, діяльність 3 власної ініціативи, не обумовлена сторонніми наказами чи зобов'язаннями; підприємець діє на свій розсуд без будь-яких застережень. По-друге, це діяльність постійного, тобто систематичного характеру. По-третє, така діяльність здійснюється на власний ризик підприємця. Це означає, що сам підприємець бере на себе відповідальність за наслідки підприємницької діяльності - як позитивні, так і негативні. У разі банкрутства підприємець не може сподіватися на державну дотацію - держава за борги підприємця відповідальності не несе. Збиток від випадкової загибелі майна також падає на підприємця. Разом з тим, характерною рисою підприємницької діяльності є іiі мета - одержання прибутку. Саме для цього і розпочинається підприємницька діяльність [12]. 
Важливим етапом переходу стартапу від «ідеї» до реального бізнесу, який у майбутньому може стати відомою та прибутковою компанією, $є$ юридичне оформлення такого проекту його засновниками. Перш за все, необхідно визначити організаційно-правову форму, яка на певному етапі найбільш підходить даному проекту.

Організаційна (організаційно-правова) форма передбачає класифікацію підприємств залежно від форм власностіта способів розмежування у підприємствах окремих форм власності і управління майном. Враховуючи, що стартап, зазвичай, на початку об'єднує спільною ідеєю невелике коло зацікавлених у іiі реалізації осіб, як початковий варіант його юридичного оформлення можна запропонувати такі форми:

- фізична особа-підприємець (ФОП);

- приватне підприємство (ПП);

- товариство з обмеженою відповідальністю (ТОВ).

Основні переваги та недоліки обрання зазначених організаційноправових форм для реєстрації стартапу наведено у табл. 2 .

Табличя 2

Переваги та недоліки організаційно-правових форм стартапу

\begin{tabular}{|c|c|c|}
\hline $\begin{array}{l}\text { Організаційно- } \\
\text { правова форма }\end{array}$ & Переваги & Недоліки \\
\hline $\begin{array}{l}\text { Фізична особа- } \\
\text { підприємець } \\
\text { (ФОП) }\end{array}$ & $\begin{array}{l}\text { - } \text { Відсутні вимоги до } \\
\text { наявності статутного } \\
\text { стартового капіталу; } \\
\text { - коротка процедура } \\
\text { реєстрації за місцем } \\
\text { проживання підприємця; } \\
\text { - } \text { контроль з боку держави } \\
\text { незначний; } \\
\text { - стартап-підприємець } \\
\text { працює самостійно і тільки на } \\
\text { себе }\end{array}$ & $\begin{array}{l}\text { - } \text { У разі невдачі проекту, } \\
\text { банкрутства, ФОП несе } \\
\text { відповідальність усім своїм майном; } \\
\text { - обмеженість стартового капіталу } \\
\text { власними коштами ФОП (або } \\
\text { незначними позичковими) }\end{array}$ \\
\hline $\begin{array}{l}\text { Приватне } \\
\text { підприємство } \\
\text { (ПП) }\end{array}$ & $\begin{array}{l}\text { - } \text { розмір статутного капіталу } \\
\text { не встановлений законодавчо, } \\
\text { тобто визначається на розсуд } \\
\text { засновників; } \\
\text { - можливість самостійно } \\
\text { визначати, як працюватиме } \\
\text { ПП, передбачивши усі істотні } \\
\text { положення в статуті }\end{array}$ & $\begin{array}{l}\text { - поняття «приватне підприємство» } \\
\text { вказує лише на форму власностіта } \\
\text { потребує законодавчого уточнення; } \\
\text { - така форма підприємства є менш } \\
\text { пізнаваною іноземними інвесторами } \\
\text { (на відміну від ТОВ, яке має } \\
\text { зрозумілий іноземцям аналог - Ltd.) }\end{array}$ \\
\hline $\begin{array}{l}\text { Товариство } 3 \\
\text { обмеженою } \\
\text { відповідальністю } \\
\text { (ТОВ) }\end{array}$ & $\begin{array}{l}\text { - } \text { розмір статутного капіталу } \\
\text { не встановлений законодавчо, } \\
\text { тобто визначається на розсуд } \\
\text { засновників; } \\
\text { - спрощена система } \\
\text { управління підприємством:; }\end{array}$ & $\begin{array}{l}\text { якщо один із учасників діятиме } \\
\text { всупереч інтересам товариства, то } \\
\text { усунути його від діяльності навіть } \\
\text { рішенням зборів учасників буде } \\
\text { складно: він повинен сам захотіти } \\
\text { піти }\end{array}$ \\
\hline
\end{tabular}




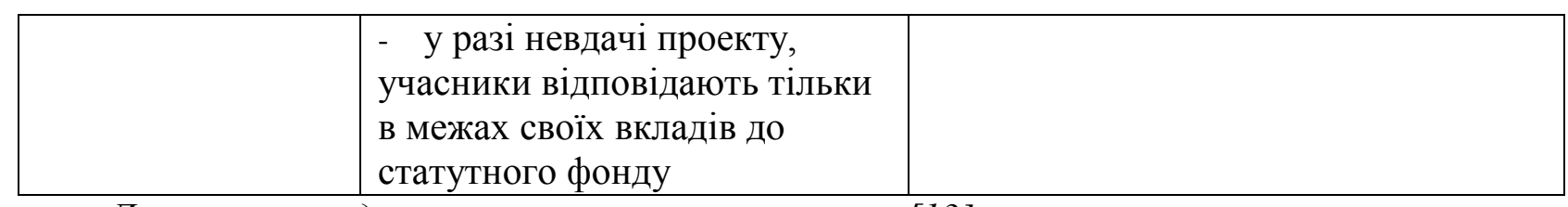

Джерело: складено авторами з використанням [13]

На момент створення продукту та залучення фінансування найлаконічнішим засобом врегулювати відносин між засновниками може стати засновницький договір без подальшого створення юридичної особи або зі створенням. У цьому договорі учасники стартапу можуть передбачити [13]:

- вільне волевиявлення всіх сторін на створення проекту;

- регулювання права інтелектуальної власності, яке належатиме творцям об'єкта інтелектуальної власності, допоки юридична особа не буде створена i дозволить розмежувати, який об'єкт належить до проекту, а який ні;

- внески засновників у проект;

- право якої країни буде застосовуватись до майбутньої юридичної особи;

- порядок внесення змін у договір.

Продукт, який учасники стартапу планують просувати на ринок, $є$ результатом їх творчої діяльності, тобто об'єктом їх інтелектуальної власності. Тому права на його використання повинні бути захищені.

Важливим питанням для учасників стартапу на етапі підготовки товару/послуги до виходу на ринок є питання його подальшого розвитку: просування товару власними силами, або продаж великій корпорації, яка, можливо, спроможна здійснити просування більш швидко та ефективно. В останньому випадку патентування не потрібно. Але якщо стартап все ж наважується на виробництво, варто залучити фахівців, які зможуть швидко та коректно визначити об’єкт та провести процедуру патентування. Серед варіантів можна зазначити: твори або комп'ютерні програми (об'єкти авторського права), корисні моделі, винаходи, промислові зразки (об'єкти патентного права) або ж ноу-хау (секрети виробництва). Універсальних рекомендацій щодо термінів отримання патенту не існує, проте діє принцип «краще раніше, ніж пізніше»[14].

Питаннями регулювання діяльності у сфері охорони прав інтелектуальної власності в Україні займається Державна служба інтелектуальної власності (ДСІВ). Тому, після створення об'єкта інтелектуальної власності авторові, який займається розробкою об'єктів для проекту, варто отримати свідоцтво, яке засвідчить його право на твір. Для цього потрібно до ДСІВ подати такі документи [15]:

- заяву;

- примірник твору (у матеріальній формі); 
- документ, що свідчить про факт і дату оприлюднення твору (за наявності);

- документ або копію документа про сплату збору за підготовку до реєстрації авторського права;

- документ про сплату збору за оформлення і видачу свідоцтва;

- довіреність, якщо заявка подається довіреною особою.

Охоронні документи України діють лише на території України. Якщо у стартапу плани закордонної експансії, потрібно уважно поставитися до вибору країн патентування При цьому витрати на іноземне патентування будуть вище в рази. Вартість залежить від країни і складається з патентних мит, що встановлюються національними патентними відомствами, і вартості послуг патентних повірених.

Регулювання відносин між учасниками стартапу також є відповідальним етапом захисту прав інтелектуальної власності. Доцільно укладати авторський договір між автором і засновниками стартапу [13]:

- про передання виключного права на використання твору: автор (чи інша особа, яка має виключне авторське право) передає право використовувати твір певним способом і у встановлених межах тільки одній особі, якій ці права передаються, і надає цій особі право дозволяти або забороняти подібне використання твору іншим особам;

- про передання невиключного права на використання твору: автор (чи інша особа, яка має авторське право) передає іншій особі право використовувати твір певним способом і у встановлених межах.

Висновки. Динамічний розвиток ринку стартапів в Україні, особливо в IT-секторі, зумовлює необхідність у визначенні особливостей правового регулювання їх діяльності та питань охорони прав наоб'єкти інтелектуальної власності. Відсутність у вітчизняному законодавстві визначення терміну «стартап» зумовлює регулювання їх діяльності шляхом використання законів та законодавчих актів відповідно до окремих напрямівдіяльності таких компаній.Важливим кроком юридичної ідентифікації стартапу є вибір його організаційно-правової форми. Враховуючи особливості їх функціонування, на початковому етапі пропонується використання однієї з таких: фізична особа-підприємець, приватне підприємство або товариство 3 обмеженою відповідальністю. 3 метою регулювання відносин між засновниками стартапкомпаній доцільно укладати засновницький договір, а длязахисту прав інтелектуальної власності - авторський договір між автором і засновниками стартапу. Реєстрацію прав на об'єкт інтелектуальної власності, у тому числі й патентування, рекомендується здійснювати відповідно до цілей проекту та із залученням фахівців. Подальші дослідження у цьому напрямі можуть стосуватись правового регулювання відносин стартап-компаній $з$ різними типами інвесторів. 


\section{Література:}

1. Кабачинский И. Умные деньги: насколько выгодны инвестиции в украинские IT-проекты [Электронный ресурс] / Илья Кабачинский, Алёна Андрусяк // ЖУРНАЛ FORBES. Март2016. - №3. - Режим доступа: http://forbes.net.ua/magazine/forbes/1412695-umnyedengi-naskolko-vygodny-investicii-v-ukrainskie-it-proekty.

2. ЗакониУкраїни«Про підприємництво»: за станом на 7 лютого 1991 p.// Відомості Верховної Ради УРСР.-1991.- №14. - ст.168.

3. Закон України «Про інвестиційну діяльність»: за станом на18.09.91 // Відомості Верховної Ради України. - 1992. - № 10. - Ст. 357.

4. Закон України «Про режим іноземного інвестування» : за станом на 19.03.1996 р. // Відомості Верховної Ради України. -1996. - № 19. - Ст. 80.

5. Закон України «Про інноваційну діяльність»: за станом на 04.07.2002 р. // Відомості Верховної Ради України.- 2002. - № 36. - Ст. 266.

6. Закон України «Про наукові парки»: за станом на 25.06.2009 р. // Відомості Верховної Ради України. - 2009. - № 51. - Ст. 757.

7. Закон України «Про авторське право та суміжні права» »: за станом на 23.12.1993 р. // Відомості Верховної Ради України. - 1994. - № 13. - Ст. 64.

8. Закон України «Про охорону прав на винаходи і корисні моделі»: за станом на 15.12.1993 р. // Відомості Верховної Ради України.- 1994. - № 7. - Ст. 32.

9. Закон України «Про охорону прав на знаки для товарів і послуг»: за станом на 15.12.1993 р. // Відомості Верховної Ради України. - 1994. - № 7. - Ст. 36.

10. Закон України «Про захист персональних даних»: за станом на 01.06.2010 р. // Відомості Верховної Ради України.- 2010. - № 347. - Ст. 481.

11. Збанацький Д. Стартапи: юридичні та практичні аспекти. Ознайомча частина [Електронний ресурс] / Денис Збанацький // Незалежний аудитор. - Режим доступу: http://n-auditor.com.ua/uk/component/na_archive/155?view=material.

12. Правознавство: Навчальний посібник. / За загальною редакцією В. Г. Гончаренка. - К.: Український інформаційно-правовий центр. - 2002. - 385 с.

13. Підодвірна Ю. Як оформити стартап: юридична тяганина [Електронний ресурс] / Юлія Підодвірна // STUDWAY. - Режим доступу: http://studway.com.ua/startup-issue/.

14. Полякова Н. Советы юриста: Как стартапу защитить свои разработки [Электронный ресурс] / Наталия Полякова // Ведомости, № 4160 от 14.09.2016. - Режим доступа: http://www.vedomosti.ru/management/blogs/2016/09/14/656845-startapu-zaschitit-razrabotki.

15. Державна реєстрація авторського права і договорів, які стосуються права автора на твір [Електронний ресурс] // Офіційний сайт Державної служби інтелектуальної власності України. - Режим доступу: http://sips.gov.ua/ua/copyright_registration.html. 